\title{
Public Sociology: Problematics, Publicity, and Possibilities
}

\author{
Lawrence T. Nichols
}

Published online: 4 December 2009

(C) Springer Science+Business Media, LLC 2009

In this issue we present six papers that deal in contrasting ways with the ongoing debate over public sociology. Considered collectively, the analyses portray the public sociology project as impossible or at least seriously hampered, but nevertheless newsworthy, diverse and sometimes triumphant. A true display of standpoint epistemology and multivocality.

Darren Noy begins with a thoughtful and highly personal critique of the ideal of public sociology as embodied in the curriculum of the University of California at Berkeley. On the basis of his experience as a doctoral student in that program, Noy expresses concern that the very rubric of "public sociology" tends toward a moral critique of "professional" sociology. This, he believes, has created entrenched factions and has pulled the field ever more deeply into what he calls a "self-referential quagmire." The way forward, he believes, is transdisciplinary research in collaboration with community actors, in the service of the common good.

Joey Sprague and Heather Laube continue in a critical vein by examining structural barriers facing colleagues interested in doing public sociology. The authors are especially interested in the experiences of women in the field. They present findings based on interviews with fifty academic feminists and fifteen other feminists engaged with public sociology. Their data point to two especially pertinent factors: (1) what the authors call the culture of professional sociology; and (2) established standards for evaluating scholarship. Sprague and Laube conclude with several recommendations for facilitating high-quality public sociology.

Mathias Revers takes the discussion in a more positive, as well as international, direction through an examination of sociologists featured in the Austrian press. He

L. T. Nichols $(\bowtie)$

Division of Sociology \& Anthropology, West Virginia University, Morgantown, WV, USA

e-mail: Larry.Nichols@mail.wvu.edu 
finds that sociologists do frequently appear in published stories, but he is concerned about the overall quality of their participation and the impact of the coverage. Revers concludes that several issues must be addressed in order for sociology to become more fully public in terms of a presence in mass media: the avoidance of publicity by sociologists, values and ideology, incompatibilities of language games, divergence of relevance criteria, and deficient cultural empathy.

Catherine Siebel and Katherine Clegg Smith continue the analysis of sociology and mass media by examining coverage of sociology by the Associated Press. They focus in particular on two research questions: (1) the circumstances in which sociological expertise is called upon in the news; and (2) the circumstances (beyond research expertise) under which sociology and sociologists are mentioned in news coverage. They find that sociology is especially important in articles on international relations, and also that certain areas of sociological research resonate more strongly than others with journalists (the top three being politics, religion, and crime and policing). Their data also indicate that institutional prestige plays a significant role, and that sociological research conducted at certain universities (e.g., Duke, Columbia, Stanford) is more likely to be publicized than work done elsewhere.

John Gabriel, Jenny Harding, Peter Hodgkinson, Liz Kelly and Alya Khan demonstrate the possibilities and alternatives of public sociology on the basis of their experience in the United Kingdom. The authors delineate three related but contrasting cases of public sociology at London Metropolitan University: the work of the Child and Woman Abuse Studies Unit, as well as courses on health ethics and a community-based oral history project. They argue that these activities do not fit neatly into the "public sociology" box of Michael Burawoy's four-cell model of the division of sociological labor. Rather, they conclude, it might be better to think of public sociology as an "interstitial" phenomenon.

Barbara Misztal concludes the discussion with an examination of the triumphs of three women sociologists, each of whom was also a Nobel Peace laureate. She celebrates Jane Addams, Emily Green Balch and Alva Myrdal as successful synthesizers of the roles of leading public intellectuals, reformers and scholars. Misztal also argues that the public sociology contributions of these exemplars were made possible by, and were indeed rooted in, their expertise as professional sociologists. She concludes that, individually and collectively, these careers demonstrate the possibilities of a sociology that is at once cosmopolitan, feminist and pacifist. 